increase in the number of students who are applying directly from secondary school. This shift could indicate a change in the reasons for student migration. I would argue that there are some Canadians studying abroad who have never applied to a Canadian medical school. These students may have chosen to apply abroad because of the attractive streamlined direct entrance from secondary school that some international medical schools offer. Although well established in Europe, direct-entry programs are relatively new in Canada: Queen's University in Kingston, Ontario, accepts only 10 students each year into its direct-entry program. ${ }^{2}$

Barer and colleagues ${ }^{1}$ fail to see the benefits of studying abroad. In 2009, at the age of 18 , I decided to study in Ireland, and it was the best decision of my life. I am entering my final year of study and am glad to say I have no regrets. In addition to receiving a great education, I have had the opportunity to travel throughout Europe both for leisure and to enhance my medical education. These experiences will stay with me regardless of where I work and will provide me with a unique set of skills that will change the way I look at and deal with difficult situations.

I wholeheartedly agree with Barer and colleagues ${ }^{1}$ that the majority of students studying abroad are disillusioned about working in Canada and need to be aware of the prospects for foreigntrained Canadian physicians. However, there will always be hope for those who take advantage of all that an education abroad has to offer.

\section{Pishoy Gouda}

Fifth-year medical student, National University of Ireland, Galway, Ireland

\section{References}

1. Barer ML, Evans RG, Hedden L. False hope for Canadians who study medicine abroad. CMAJ 2014;186:552.

2. Queen's University Accelerated Route to Medical School (QuARMS). Kingston (ON): Queen's University. Available: www.queensu.ca/admission/programs /quarms.html (accessed 2014 Apr. 9)

CMAJ 2014. DOI:10.1503/cmaj.114-0064

To my considerable surprise, I found myself agreeing with everything that Barer and colleagues ${ }^{1}$ wrote in their CMAJ salon article. The authors are right in describing Canadian health care as an "essentially unmanaged system where physicians can practise what they want, where they want, when they want."

It was not always thus. I came to British Columbia with my wife and three children 50 years ago and was told by the College of Physicians and Surgeons of British Columbia that I would have to work in an underserviced town or city in northern $\mathrm{BC}$. This seemed perfectly reasonable, and so, I went to work in Prince Rupert, BC.

All this has been changed by the Canadian Charter of Rights and Freedoms, which guarantees all Canadians and permanent residents freedom of mobility within Canada to pursue their occupation. Ironically, the same charter offers no "right to health care," although most Canadians assume it does. Until these two conflicting aspects of the charter are dealt with, we shall continue to see a very disturbing maldistribution of doctors throughout Canada, with rural Canadians, who produce much of the nation's wealth, being shortchanged.

To open the gates to all Canadian medical graduates from overseas would offer no guarantee of better health care to those Canadians living in rural and isolated areas.

We have a politicized health care system, and it seems that no federal government has the courage to address its problems.

\section{Robert G. Holmes MD}

Retired rural surgeon and general practitioner, Nicola Valley, BC

\section{Reference}

1. Barer ML, Evans RG, Hedden L. False hope for Canadians who study medicine abroad. CMAJ 2014;186:552.

\section{CMAJ 2014. DOI:10.1503/cmaj.114-0067}

The bleak picture and much of the statistical information Barer and colleagues ${ }^{1}$ present for Canadians studying abroad who want to enter Canadian residency programs are accurate. The authors conclude that the road is very dark and difficult for these brave and enterprising students who return home to practise medicine.

I would also advise Canadians who study medicine abroad that if they were to continue their postgraduate medical education and training in specified foreign jurisdictions, they could obtain Canadian medical training equivalency and then re-enter Canada on equal footing with their Canadian-trained colleagues. Specifically, Canadians who study abroad, complete their family medicine/general practice training and obtain certification in the United States, United Kingdom, Ireland, Australia or New Zealand are eligible for certification by the College of Family Physicians of Canada, possibly without writing the examinations. Further, depending in which Canadian province they choose to practise, they may also be exempt from the Medical Council of Canada examinations.

Canadians who choose to complete their specialty training and obtain certification in one of several recognized jurisdictions across the globe, can become eligible to write the corresponding Royal College of Physicians and Surgeons of Canada examinations and obtain certification before or after their return to Canada.

Alternate pathways exist via specific provincially managed medical assessment programs. These programs are typically targeted toward specific medical disciplines in high-need communities and can change over time. Therefore, a careful evaluation of the program and medical credentials must be completed before making such a commitment.

Unfortunately, the authors ${ }^{1}$ chose to present only the bleak side of this issue, rather than research more deeply to uncover alternative global medical education options. We can guide Canadians who study abroad back to Canada, with their heads held high with pride.

Canadians studying medicine abroad should consult with a Canadian physician recruitment specialist to help plan their return home, on their own terms.

\section{Phil A. Jost MBA}

Vice President and Regional Manager, CanAm Physician Recruiting Inc. (PEI, New Brunswick, Alberta and Saskatchewan), Summerside, PEI

\section{Reference}

1. Barer ML, Evans RG, Hedden L. False hope for Canadians who study medicine abroad. CMAJ 2014;186:552.

CMAJ 2014. DOI:10.1503/cmaj.114-0066 